Chirurgia (2020) 115: 267-273

No. 2, March - April

Copyright@ Celsius

http://dx.doi.org/10.21614/chirurgia.115.2.267

\title{
Giant Cavernous Hemangioma of the Right Atrium - A Rare Case and Literature Review
}

\author{
Felix Dobritoiu', Horatiu Moldovan ${ }^{2,3}$, Rodica Oncica', Gabriel Vasile', Elena Nechifor', Catalin Copaescu ${ }^{1,4}$ \\ ${ }^{1}$ Ponderas Academic Hospital Bucharest, Romania \\ ${ }^{2}$ Sanador Hospital, Bucharest, Romania \\ 3"Titu Maiorescu" University of Medicine, Bucharest \\ "'Grigore T Popa" University of Medicine and Pharmacy, lasi, Romania
}

Corresponding author: Catalin Copaescu, MD PhD Associated Professor of Surgery Ponderas Academic Hospital Nicolae Caramfil Street, no. 85 A district 1, Bucharest, Romania

E-mail: catalin.copaescu@ponderas-ah.ro

\section{Rezumat}

Hemangiom cavernos gigant dezvoltat la nivelul atriului drept - prezentare de caz rar și revizuirea literaturii

Pacienta în vârstă de 52 ani, asimptomatică, fără antecedente personale patologice semnificative, se prezintă în serviciul de chirurgie toracică pentru excizia unei formațiuni tumorale mediastinale, diagnosticată la un examen ecografic de rutină. Investigațiile au fost extinse cu ecografie cardiacă, ecografie transesofagiană, RMN şi CT toracic, investigații care au sugerat o poziție paracardiacă a formaăiunii tumorale. S-a decis astfel practicarea toracoscopiei exploratorie, în vederea stabilirii rezecabilitații tumorale. Intraoperator s-a observat că formațiunea tumorală este dezvoltată intrapericardic, şi pentru a se putea evalua palpator s-a practicat sternotomie mediană şi abord intrapericardic. Formațiunea tumorală invada atriul drept pe o suprafață mare şi nu putea fi rezecată fără circulație extracorporeală şi cardioplegie. Pacienta a fost transferată în secția de chirurgie cardiovasculară şi la 7 zile postoperator s-a intervenit iterativ sub by-pass cardiopulmonar, cu excizia completă a leziunii tumorale şi reconstrucția celor două atrii cu pericard autolog şi bovin. Evoluția postoperatorie a fost favorabilă, fără complicații majore, raportul de anatomie patologică arătând că leziunea tumorală a fost un hemangiom cavernos.

Concluzii: caz rar de angiom cavernos gigant, localizat la nivelul cordului, dificil de diagnosticat, ce a necesitat colaborare multidisciplinară, seriată. 
Cuvinte cheie: hemangiom cavernos, tumori cardiace, toracoscopie video-asistată, rezecție tumoră cardiacă, reconstrucție atrială

\begin{abstract}
A 52 years old woman, asymptomatic, with no significant medical history, presented to a thoracic surgery department for excision of a giant mediastinal mass that was incidentally detected during a routine abdominal ultrasound. Various imaging methods (echocardiography, chest X-ray, CT-scan, MRI) located the mediastinal mass as paracardiac and the excision using video-assisted thoracoscopic surgery (VATS) was proposed, in general thoracic surgery department. Although initially considered a paracardiac mass, intraoperatively the tumor location proved to be intrapericardial. Reaching the limits of VATS, a median sternotomy and longitudinal pericardiotomy were performed, demonstration a right atrium tumor with intrapericardial extension. At this stage, the excision was considered impossible without cardiopulmonary bypass and cardiac arrest. Having this information, the case was deferred to cardiovascular surgery, one week after and, a complete resection of the tumor was performed without incidents. Both atria were reconstructed with patches of autologous and bovine pericardium. The postoperative outcome of the patient was very good and the histopathology report showed that the tumor was a cavernous hemangioma. The literature was reviewed for this pathology.

Conclusion: a rare case of a giant cavernous hemangioma of the heart, with diagnostic pitfalls had a successful multidisciplinary staged approach .
\end{abstract}

Key words: cavernous hemangioma, cardiac tumors, video-assisted thoracoscopy, cardiac tumor resection, atrial reconstruction

\section{Introduction}

Cardiac tumors are very rare lesions, with an incidence of $0.3 \%$ to $0.7 \%$ (1). Due to the fact that most of the cardiac tumors are diagnosed postmortem, the data is not only collected from surgery and cardiology departments but, also from autopsy reports (2).

The vast majority of the cardiac tumors are benign. Only $1 / 4$ th of all are malignant, with sarcoma being the most diagnosed one (approximative $75 \%$ of all malignant cardiac tumors) (1).

We report a case of a giant cardiac cavernous hemangioma in a 52 years old female patient with no comorbidities and no symptomatology. The literature was reviewed for this pathology.

\section{Case report}

A 52-year-old female patient underwent a rou- tine abdominal ultrasound examination which indicated a large hyperechoic mass located in the proximity of the heart, with well-defined margins and measuring 105/75mm.

Transthoracic echocardiogram (TTE) and transesophageal echocardiogram (TEE) confirmed the presence of a giant mass located in the middle mediastinum, in contact with the right atrium and interatrial septum, but both of the tests revealed normal cardiac function $(\mathrm{EF}=60 \%)$. The possibility that the mass is a right atrial myxoma was not excluded by the ultrasonography tests, but no mass could be seen into the right atrium.

The cardiac MRI revealed a solid mediastinal mass with well-defined margins, measuring 120/80/76mm, in close contact with the superior vena cava, the right atrium, the interatrial septum, the left atrium, right pulmonary artery and pulmonary trunk, and both right pulmonary veins. Although the mediastinum was shifted to the left by 

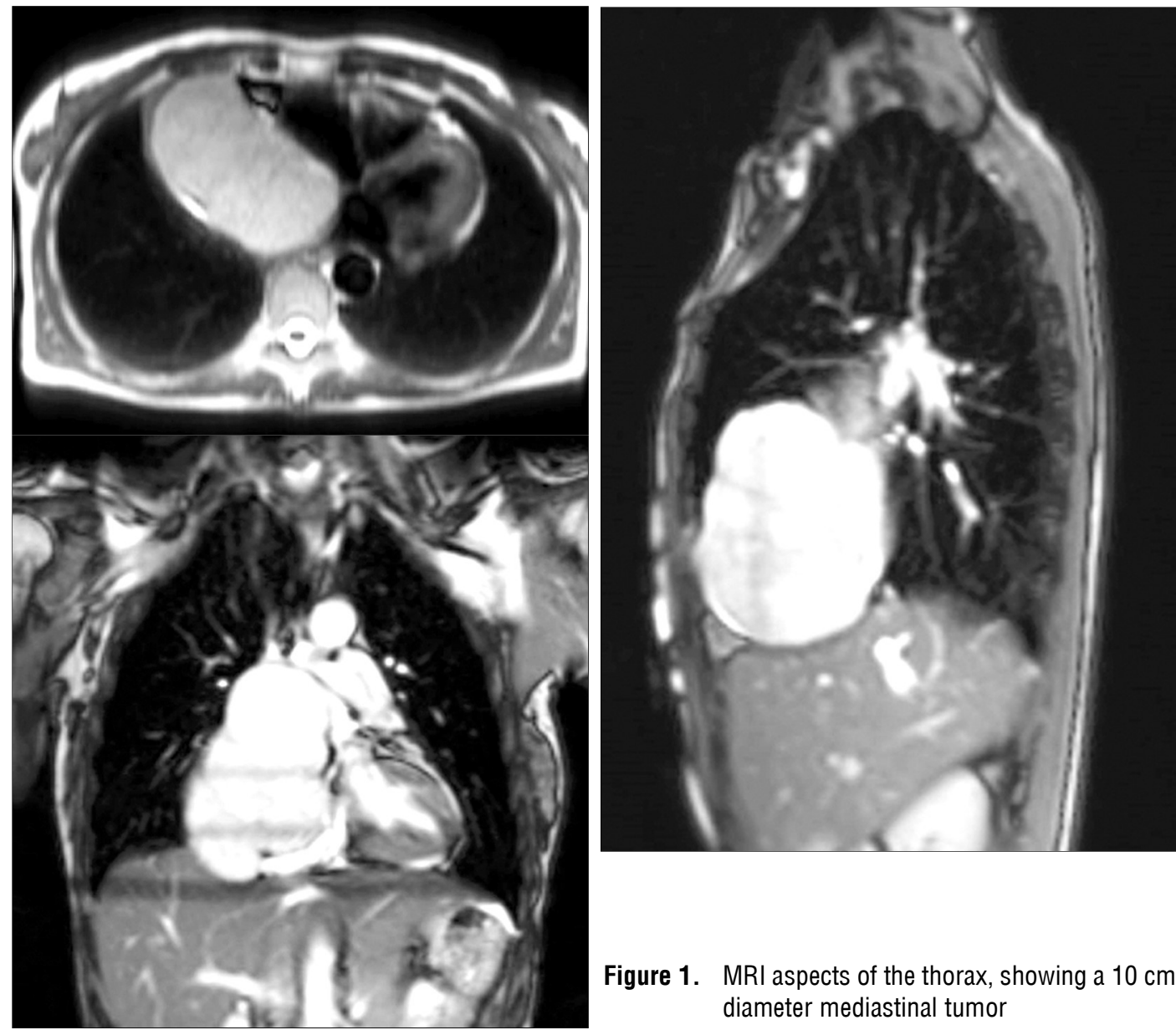

Figure 1. MRI aspects of the thorax, showing a $10 \mathrm{~cm}$ diameter mediastinal tumor

compression, the cardiac wall does not looked involved by the mass Fig.1.

Thoracic CT scan (Fig. 2) showed that the tumor was in close contact with all three lobes of the right lung, and with the right hemidiaphragm in the cardiophrenic angle.

None of the above-mentioned tests could specify if the tumor is involving the heart or not, and which is the origin. Consequently, we decided to perform an exploratory thoracoscopy with biopsy and to assess the tumors resectability. An informed consent was signed by the patient.

The patient was placed in a supine position, with the right hemithorax slightly elevated. The orotracheal intubation was performed with a $35 \mathrm{Fr}$ double-lumen tube, and the right lung was deflated. We used a three-port approach with access into the pleural cavity through the 5th intercostal space midaxillary line, 7th intercostal space midaxillary line, and 6th intercostal space anterior axillary line. The right lung was deflated and without adhesions to the chest wall or diaphragm but was completely adherent to the mediastinal pleura.

After the dissection of the adhesions and liberating the superior vena cava, the pericardium, the right phrenic nerve, the pulmonary artery and veins (Fig. 3), the right atrium could be seen moving freely, through the transparency of the pericardium. We performed a $2 \mathrm{~cm}$ section of the anterior pericardium followed by a rhythmic herniation of the right atrium. Because of the dimensions of the tumor, we could not evaluate deeply into the pericardium with a thoracoscopic approach, so that we decided to perform a median sternotomy for the need of a palpatory assessment. 

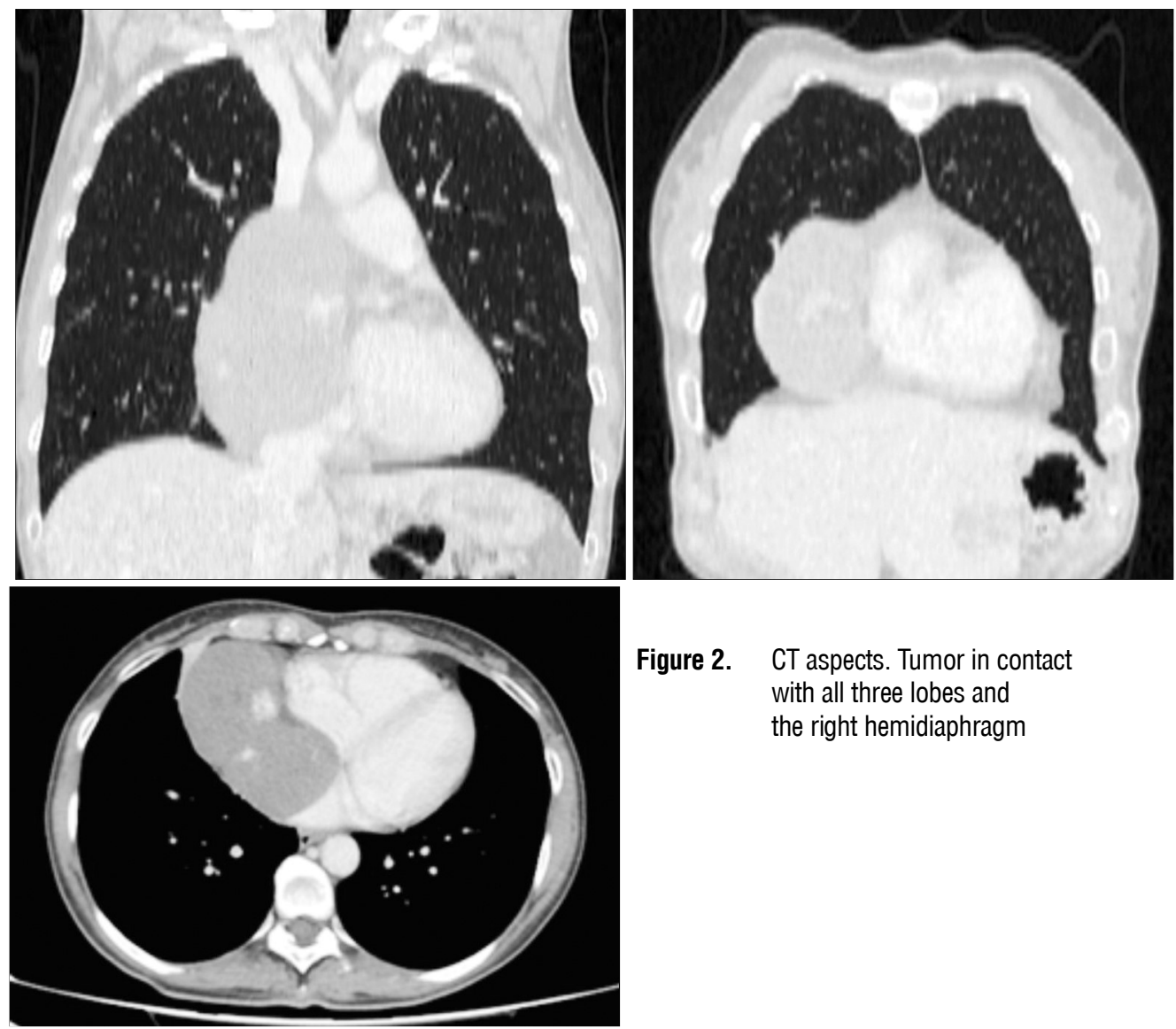

Figure 2. CT aspects. Tumor in contact

with all three lobes and

the right hemidiaphragm
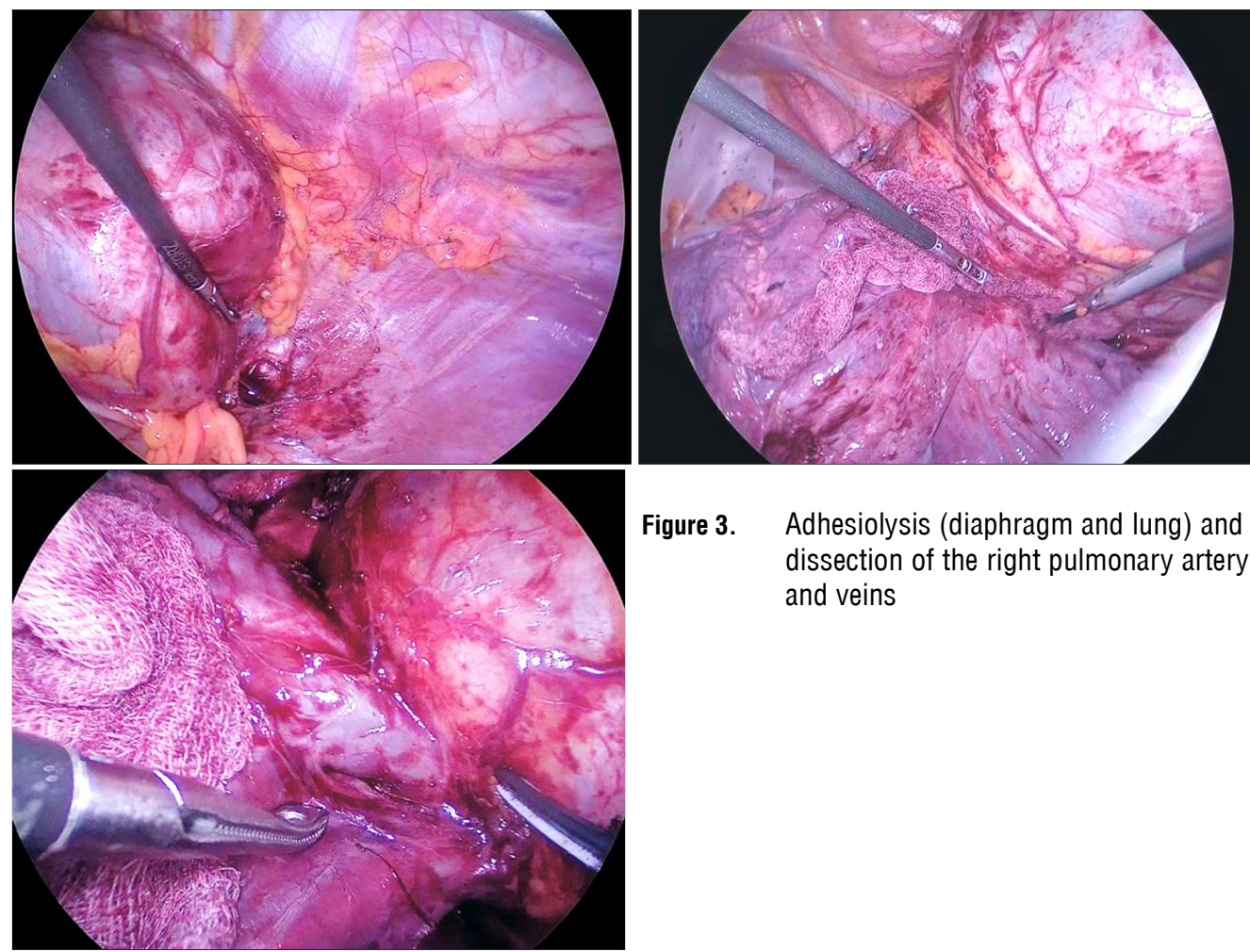

Figure 3. Adhesiolysis (diaphragm and lung) and dissection of the right pulmonary artery and veins 

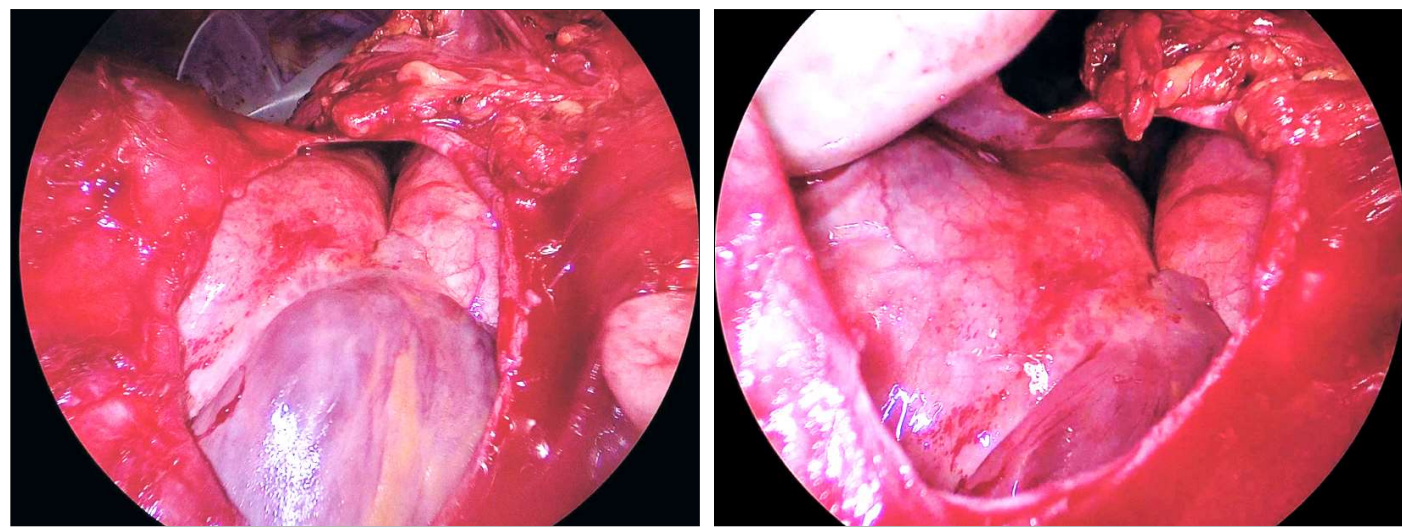

Figure 4. Pericardiotomy: large mass involving the right atrium and the pericardium

After the pericardiotomy and deep palpation, we concluded that the tumor was part of the right atrial wall and was stretching to the left atrium and the pulmonary trunk Fig. 4.

Dense adhesions to the internal surface of the right pericardium, the superior vena cava and the pulmonary artery were demonstrated. Both right pulmonary veins were pushed downwards and compressed.

Since the resection could not be performed without extracorporeal circulation, we have concluded the exploration after 125 minutes and deferred the patient to cardiovascular surgery department.

One week later, after the patient signed an informed consent, an iterative median sternotomy was performed. After opening the thoracic cavity and pericardium, a large tumoral mass, developed between the right and the left atrium, in the posterior interatrial groove, was exposed. Also, the mass was in close contact with the superior and inferior vena cava.

Surgery was performed under cardiopulmonary by-pass with aortic and bi-caval cannulation (direct cannulation for the superior vena cava and peripheral cannulation via the iliac vein for inferior vena cava) (Fig. 5). Dissection of the tumoral mass was performed on beating heart. Using a sharp and blunt dissection, a large amount of tumoral mass was removed, except for a small posterior fragment that was inserted on the right and left atrium walls.

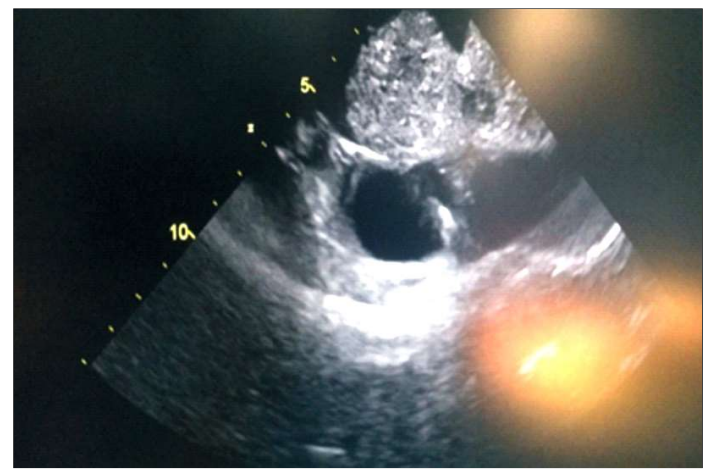

Figure 5. Inferior vena cava cannula insertion with echoguidance help

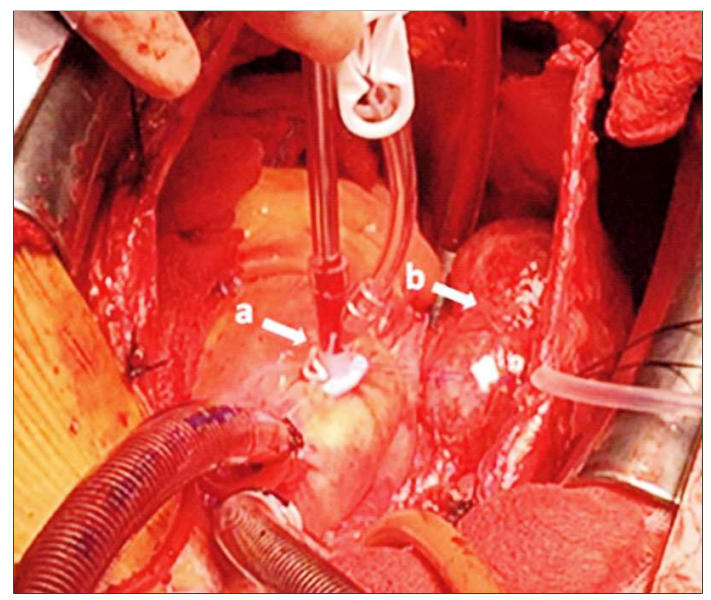

Figure 6. Insertion of a cardioplegic needle in order to arrest the heart. a - cardioplegic needle b - right atrial tumor

In order to dissect and dislodge this later portion, the heart was arrested by aortic cross-clamping and cardioplegic solution was administered in the ascending aorta (Fig. 6). 


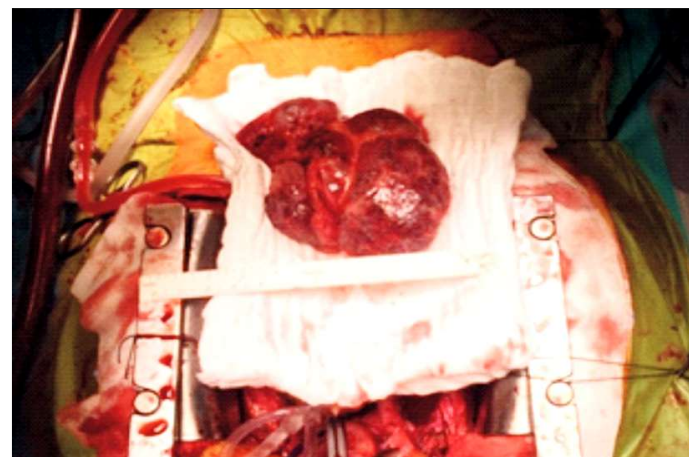

Figure 7. Macroscopic view of encapsulated tumoral mass, after excision (11 cm diameter), and transected aspect
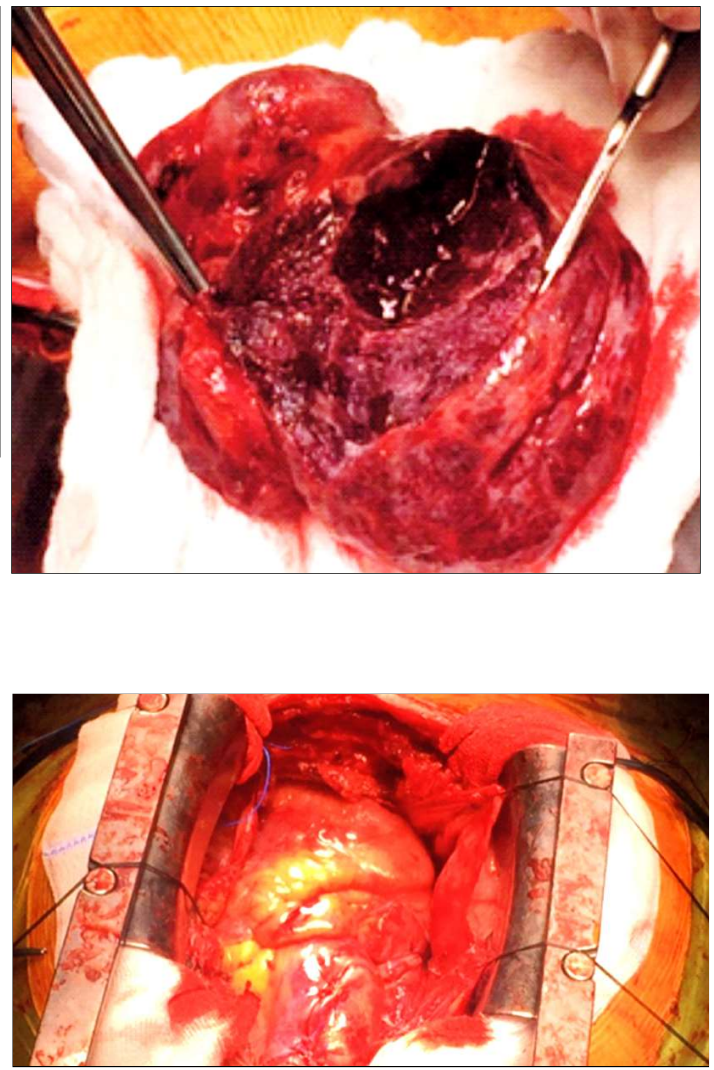

Figure 8. Final aspect after atrial reconstruction

tion. From them, only 23\% were found in the right atrium. The rest were found in the ventricles $(70 \%)$ and interatrial septum (7\%) $(4,5)$.

In a more recent study, published in 2019 , that reviewed the database of PubMed, Embase, Sinomad, CNKI, Wanfang, and VIP, a number of 67 cases, published between 1996 and 2018, were found. 65 were surgery cases and in only 23 cases the cardiac wall needed reconstruction (21 with pericardial patches and 2 with sutures only) (6).

In most cases we reviewed, echocardiography was the diagnostic tool of choice, having a specificity between $85 \%$ (7) and 95\% (8), the MRI an CT scan being used only in selected patients, where echocardiography was unsatisfactory.

Transesophageal echocardiography is superior to transthoracic echocardiography when dealing with small tumors $(<5 \mathrm{~mm})$ or tumors located in the posterior segments and is a very good intermediate imaging tool (8). 
In our case, the tumor was also diagnosed with echocardiography and confirmed with other imaging tools, but neither the echocardiography, esophageal echocardiography, MRI nor CT scan could make it clear if there is an intra or extra-pericardial mediastinal tumor.

$68 \%$ of the patients suffering from atrial hemangioma are symptomatic, with pain, dyspnea and arrhythmia being the most frequent symptoms, and $32 \%$ of them are asymptomatic. (6) There is a correlation between the dimension of the lesion and the symptomatology. Most of the asymptomatic patients have small tumoral lesions, under $100 \mathrm{~mm}$ in diameter. In all the articles that we reviewed only one patient was asymptomatic and had a large lesion of $110 / 65 \mathrm{~mm}$.

Even though our patient was asymptomatic we decided to perform the surgical resection of the tumor, because atrial tumors have a high risk of thrombosis or embolism and surgery with resection is indicated as soon as possible.

Video-assisted thoracoscopic surgery (VATS) was the first approach because all the preoperative investigations suggested that the lesion was a right paracardiac mediastinal tumor, and we wanted to minimally invasive assess its resectability. We have decided to perform a median sternotomy because intraoperatively, after dissection, from that prospective, the lesion seemed to be a pericardial one, and the anterior part of the right atrium was clearly seen free above the tumor, through the transparency of the pericardium. At that stage, we have suspected a pericardial fibroma and decided to palpatory asses the lesion intrapericardial.

Since after sternotomy it was proven that the resection cannot be performed without extracorporeal circulation, it was decided to conclude the VATS approach and the cardiovascular surgeon completed the multidisciplinary team.

The complete resection of the tumor was performed without incidents, one week after in a cardiac surgery department. The histopathology report revealed a cavernous hemangioma. The literature was reviewed for this pathology. The recurrence of a benign tumor is considered to be very low, with an accepted 5-year survival rate of $83 \%$ (6).

\section{Conclusions}

Even though the imagistic "arsenal" improved over time, and transthoracic and transesophageal echocardiography, x-ray, CT scan, and MRI seem to be infallible when corroborated, large tumors of the middle mediastinum still represent a diagnostic challenge.

Cavernous angioma of the heart is a benign lesion, but with a high grade of invasion in the adjacent structures. In this case both atria, the interatrial septum, the pericardium, and part of the superior pulmonary vein were invaded.

Being a vascular proliferation of the heart, with a very high risk of hemorrhage, caution should be taken when dealing with this type of lesion without cardiopulmonary by-pass.

\section{Conflict of Interest}

The authors have no conflict of interest and no financial support to declare.

\section{References}

1. Leja MJ, Shah DJ, Reardon MJ. Primary cardiac tumors. Tex Heart Inst J. 2011;38(3):261-2.

2. Jonjev ZS1, Torbica V, Vučković D, Kosjerina Z. Cavernous hemangioma of the heart. Herz. 2014;39(6):716-7.

3. About cavernous angioma. Angioma Alliance. [Online] [Cited: 04 28, 2020.] http://angioma.org/pages.aspx?content $=62 \& i d=50$.

4. Perk G, Yim J, Varkey M, Colvin SB, Tunick PA, Kronzon I. Cardiac cavernous hemangioma. J Am Soc Echocardiogr. 2005;18(9):979.

5. Kojima S, Sumiyoshi M, Suwa S, Tamura H, Sasaki A, Kojima T, et al. Cardiac hemangioma: a report of two cases and review of the literature. Heart Vessels. 2003;18(3):153-6.

6. Miao H, Yang W, Zhou M, Zhu Q, Jiang Z. Atrial hemangioma: a case report and review of the literature. Ann Thorac Cardiovasc Surg. $2019 ; 25(2): 71-81$.

7. Esmaeilzadeh M, Jalalian R, Maleki M, Givtaj N, Mozaffari K, Parsaee M. Cardiac cavernous hemangioma. Eur J Echocardiogr. 2007:8(6):487-9.

8. Paraskevaidis IA, Michalakeas CA, Papadopoulos $\mathrm{CH}$, AnastasiouNana M. Cardiac tumors. ISRN Oncol. 2011;2011:208929. 